\title{
Napoleońskie ślady w twórczości Kazimierza Brodzińskiego
}

Grzegorz Zając 


\section{Grzegorz Zając}

\section{Napoleońskie ślady w twórczości Kazimierza Brodzińskiego}

$\mathrm{P}$ owiedzmy wprost: nie o śladach należałoby w tym przypadku mówić. Nic o śladach, a raczej o ściezce, literackim szlakı, jakim podążał w pewnym fragmencie swojego pisarskiego życiorysu Brodziński-poeta, a którego to trasę wyznaczały doświadczenia Brodzińskiego-żołnierza cesarskiej armii. To rodzące się na ich kanwie refleksje - bywało, że odżywające w formie wspomnienia - stanowily wtedy o kształcie lirycznych wynurzeń późniejszego twórcy Wiesłan'a; o tym, co z pewną emfazą nazwać by można jego twórczością napoleońską.

Ramy niniejszego szkicu nakazują ograniczyć się do bliższego oglądı jedynie kilku tekstów — owych śladów właśnie - trzeba mieć zatem na uwadze, że te ostatnie, choć dość wyraźne, przez co ulatwiające prześledzenie kolejnych etapów nie tylko poetyckich przemyśleń pisarza z tamtych lat, nie mówią wszystkiego o jego muzie z „okresu młodzieńczych prób"'.

Zastrzeżenie to nie pojawia się tutaj zresztą wylącznie jako element swoistej topiki otwarcia, Brodziński to wszak jeden z tych — zbyt licznych, niestety — twórców polskiego oświecenia, na którego recepcji ważyły zawsze krzywdzące stereotypy. A przecież niepodlegająca dyskusji przynależność poety do sentymentalnego nurtu ówczesnej poezji, osadzona w dodatkı w jego wypowiedziach krytycznych, nie powinna usuwać z pola widzenia niejednorodności tego pisarstwa, dającej się przy tym 
uchwycić nie tylko w perspektywie diachronicznej, ale i w obszarze każdego z kolejnych jej segmentów.

Ten z nich, który nas tu najbardziej interesuje, pozostaje dobrą tego zjawiska ilustracją. Jednym ze źródeł kształtującego się wówczas sentymentalizmu Brodzińskiego jest bowiem - raz jeszcze powołajmy się na lubelskiego badacza — „wyjątkowa” wrażliwość pisarza „na sprawy otoczenia”. Okolicznościowy charakter powstających wówczas wierszy przekłada się nierzadko na elegijną tonację lirycznego wyznania, a ta w ujęciu autora rozprawy O klasyczności $i$ romantyczności była nie mniej istotnym składnikiem modelu literatury czułej niż traktowana na ogół niby jego ikona sielankowość. Realistyczna obserwacja nie musi więc, jak się okazuje, niwelować możliwości otwarcia się piszącego na tyleż stylistyczne, ile antropologiczne wyznaczniki poezji z kręgu „szczęścia w ograniczeniu”. Fenomen tej ostatniej nie tkwił przecież - co po latach skonstatuje sam autor — w „pieszczotach Dafnisów arkadyjskich”, ale raczej w byciu „posłanką pięknych dązeń moralnych"”.

Przenikanie się tych tonacji współgrało z nicjednolitością literackich reakcji Brodzińskiego tak na osobę samego Napoleona, jak i na to, co przy olbrzymim udziale tegoż rozgrywało się na oczach Polaków doby Księstwa Warszawskiego. Za entuzjazmem, będącym funkcją nastrojów panujących po kolejnych sukcesach francuskiego wladcy, pójść miały z czasem gorycz i nostalgia, uzasadniające po części sformułowaną już współcześnie opinię, jakoby twórcę Żotnierza nad rzekq Mosku'ą... należało postrzegać w roli barda pierwszego ze straconych pokoleń w naszej literaturze+.

Swoją poetycką wędrówkę u boku Bonapartego zaczął wszelako Brodziński — naówczas ledwie osiemnastolatek, który dopiero co, po ucieczce z ziem zaboru austriackiego wstapil do polskiej armii — od Odp', pisanej w sierpniu 1815 roku, „w dzień urodzin Napoleona Wielkiego, Cesarza Francuzów, Króla Wloskiego, Protektora Ligi Reńskiej", a wpisującej się w obecną już wtedy od lat kilku w naszej poezji, związaną z postacią Korsykanina konwencję laudacyjną, znaczoną nazwiskami takich tuzów postanisławowskiego rymotwórstwa jak Franciszek Wężyk, Ludwik Osiński, a zwłaszcza Kajetan Koźmian, autor ód Na zau'ieszenie ortón' francuskich u' Lublinie czy Na pokój u' roku $1809^{5}$.

\footnotetext{
Cz. Zgorzelski, Sumienie oly'untelskie poezji Brodzińskiego, w: idem, Od ósuiecenia ku romantyzmowi i 1 'spótczésności, Kraków 1978, s. 123.

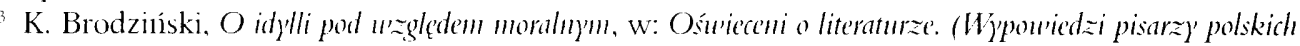
1801-1830), red. Z. Goliński. T. Kostkiewiczowa, Warszawa 1995, s. 234.

+ D. Zawadzka, Cz) istmiato pokolenie klgski 1812 roku? (Brodzinski, Fredro, Malczeu'si), w: Na przetomic

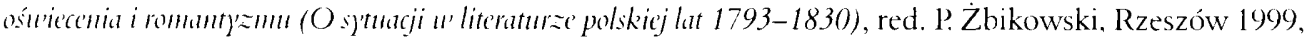
s. 268.

5 Fragmenty wszystkich z omawianych wierszy Brodzińskiego przytaczamy za: K. Brodziński, Poezje, oprac. Cz. Zgorzelski, t. 1-2, Wroctatwo: 959 \%
} 
Różnie oceniana przez badaczy, nie najlepiej zaś chyba po latach przez samego poetę, który nie włączył jej do przygotowanego przez siebie dwutomowego wydania Pism", Oda jest jedynym tekstem pisarza, gdzie tak ostentacyjnie wyrażony zostaje przezeń zachwyt nad osobą tego, za którego sprawą „pękły niewinnym, [zaś] zdrajców okowały pęta”. Zacznijmy od stwierdzenia, że intensywność tej apoteozy - wprowadzonej w jedenaście uderzających rytmiczną regularnością strof, mających przez to oddawać w jakimś stopniu marszową siłę „kroku Napoleona”, na którego dźwięk „granic wartujące skały [...] dumny kark zginały" - posiadała szereg uwarunkowań pozaliterackich. Huczne obchody urodzinowej uroczystości w Krakowie, gdzie stacjonował już wówczas świeżo upieczony artylerzysta Brodziński; euforia po wygranej wojnie z Austrią, skutkującej przyłączeniem do terytorium Księstwa ziem przejętych przez nią po III rozbiorze, wreszcie tłumacząca się nie tylko młodym wiekiem, ale i odkrywaniem na nowo przez autora swojej polskości po latach podlegania szkolnemu niemczeniu podatność na patriotyczne uniesienia ${ }^{7}$ - tworzyly atmosferę sprzyjającą bez wątpienia powstaniu utworu, w którym wielopłaszczyznowa refleksja niekoniecznie byłaby czymś oczywistym. Tekstı, w odniesieniu do jakiego to nie poetycka oryginalność pozostawała naczelnym kryterium oceny.

Mimo wynikających z podobnego stanu rzeczy słabości ody Brodzińskiego, wydaje się, że broni się ona tyleż jako literackie juwenilium, ile jako świadectwo określonych emocji, które wywoływał w polskim społeczeństwie latem 1809 zwycięzca spod Wagram. Siłę tych emocji dobitnie ukazuje autor zwłaszcza w tych fragmentach wiersza, gdzie wyraźnie słyszalna staje się tonacja mesjanistyczna. Na razie, rzecz jasıa, nie chodzi o rozpościeranie wizji Polski-mesjasza zniewolonych narodów ${ }^{\$}$. Tutaj "zbawcą”, który objawił się „sprawiedliwemu” - w tej roli "gnçbieni wiçzieniem [...] synowie Lecha" — okazuje się Napoleon, niewymieniany zresztą z imienia w pierwszej, „narracyjnej” części utworu, ujmowany tam bowiem alegorycznie jako „orzeł złoty”, co nie tylko pozwalało odwołać się do symbolicznej wspólnoty obu nacji, ale znajdowało także nzasadnienie w poetyckiej logice tekstu. Blask płynący od złotego orła i mający poprowadzić „blądzących [do tej pory] za Ojczyzny cieniem” Polaków porównano tu mianowicie do światłości bijącej z Boskiego majestatu, dającej oparcie zagubionemu „w ciemnym [...] lesie”, niczym bohater Dantejskiego arcydzieła, „wędrownikowi”. Na tej paraleli,

\section{"Idem. Pisma, t. 1-2, Warszawa 1821}

7 Por.: K. Brodziński, Wspomnichia mojej mfodości i imme pisma autobiograficanc, Kraków 1928. Skądinąd, intensywna germanizacja, której, jak i inni uczniowie szkółki elementarnej w Lipnicy Murowanej, a potem tannowskiego gimnazjum, był poddawany, przyniosła poecie... świetną znajomość niemieckiego, co zaowocować miało z czasem licznymi thumaczeniami. Były również wśród nich, co ciekawe, przekłady antynapoleońskich tekstów H. Collina (Lieder ocsterreichischer Wehrmännter), pow'state niedługo po wiedeńskim wydaniu jego zbioru w $1808 \mathrm{r}$.

* To nastapi w ostatniej. polistopadowej fazie twórczości poety - w tekstach takich jak poemat Rocznica czy wiersz rozpoczynający się od słów "Palma Clırystus obdarzył narody zbawione...". 
nieunikającej odwolań do narodowej mitologii („dawne Lecha gniazdo”, „gruzy Wawelu”), nieprzypadkowo operującej przy tym apokaliptycznym zgoła obrazowaniem", buduje poeta swoje wyobrażenie początku stawania się nowego świata.

Naturalną konsekwencją takiego ujęcia dziejów musiała być w posilkującej się mową wysoką odzie uroczysta, pełna patosu, bo też nasycona hiperbolami pochwała tego, który dał Polakom „nową ziemię”. I rzeczywiście, druga partia utworu realizuje poprzez sekwencję mających różnych adresatów apostrof taką właśnie formulę. Pośród nich — obok „tkliwego ludu”, „bardów słowiańskich”, a nawet „,murów Krakusa”, ponaglanych do głoszenia Napoleońskiej chwały — jest również sam Bóg, co skutkuje wprowadzeniem w obszar apologii poetyki modlitwy i osłabia nieco tym samym dającą znać o sobie w tej części wiersza konwencjonalność wypowiedzi. Ta prośba do „Władcy niepojętego" o błogosławieństwo dla cesarza (,Spraw, niech te wszystkie świata i miejsca, i wieki / Napoleona z swojej nie puszczą opieki”) przydaje zakończeniu debiutanckiej ody Brodzińskiego charakteru niemal psalmicznego, dziwić to wszakże nie może, skoro na przestrzeni całego tekstu francuski wladca przedstawiany byl jako Boży pomazaniec.

Sytuacja zwycięskiego pokoju, a w takiej przecież, po traktacie w Schönbrunn, powstawał ów panegiryk, nie byla jednak w tantych latach sytuacją trwałą. To, że kilkuletni żywot Księstwa zdominowany był przez stany wojennego zagrożenia, przekładało się w jakimś stopniu na ówczesne życie literackie, choćby w tym jego wymiarze, który łączyć należy z popularnością określonych form gatunkowych. Widać to również w twórczości Brodzińskiego, i to może szczególnie tam, gdzie przywołuje on postać Bonapartego. W wicrszach bliższych raczej w swej funkcji - niezależnie od wielu różnic między nimi - wojskowej pobudce niż utworom odwołującym się do klasycystycznego wzorca liryki pochwalnej.

Za podobne teksty uchodzić mogą stworzony jeszcze przed Odq, najprawdopodobniej w czasie opuszczania Warszawy przez wojska księcia Józefa wiosną 1809 r., utwór Do urojsk polskich i - w przeciwieństwie do tegoż wydrukowany za życia autora, choć, jak i Oda, nieumieszczony przez niego w wydaniu zbiorowym - Wiersz dnia 8 marca 1813 mapisany', znany także pod tytułem $N a$ odcjścic do Saksoniii" ${ }^{11}$. Odmienna niż poprzednio konwencja obu liryków sprawiła, że Napoleon nie pojawia się już tutaj jako obiekt wymykającego się doraźności, religijnego w istocie, kultu. To przede wszystkim osoba, którą przypomina się, by podtrzymać żohnierskie morale; tyleż pobudzić do walki przeciw „wiarołomnym ludom”, ile po prostu wskrzesić nadzieję, co szczególne znaczenie musiało mieć w przypadku drugiego z wymienionych utworów, na którego

\footnotetext{
„Aż razem walczą wiatry, wkoło drzewa leca, / Szumią clımury nadęte, błyski nieba świecą” - czytamy w czwartej strofie utworu.

"Zob. np.: B. Gubrynowicz, Kazimiezz: Brod-iniski Życiedd dzicła, cz. 1, Lwów 1917, s. 139.
} 
kształt nie pozostawały zapewne bez wpływu nie tylko obiektywne skutki rosyjskiej klęski cesarza, ale i osobisty dramat autora, jakim byla śmierć jego brata Andrzeja, poniesiona podczas wyprawy na Moskwę ".

Tym, co lączy bez wątpienia ten ostatni tekst z wierszem Do u'ojsk polskich, jest motyw ojczyzny ukazanej poprzez personifikacje powstającej z mogily Matki. O tyle to jeszcze istotniejsze, że jej obraz determinuje pojawienie się postaci samego Napoleona. We wcześniejszym z tych utworów bezpośrednio wzmiankuje się o nim tylko raz, właśnie wówczas, gdy, rozpoczynając sugerowany tytulem apel, podmiot wiersza odwołuje się do momentu „ocucenia” Polski z grobowego „snu”. To cesarskiemu „mieczowi” zawdzięczamy „skruszenie” tego grobu — zdaje się przypominać .jej synom”, nie pozostawiając wątpliwości, że miarą ich patriotyzmu będzie gotowość pójścia Napoleońskim śladem.

Inaczej postać Bonapartego objawi się w wierszu z roku 1813, co wynikać będzie z odmienności samej sytuacji lirycznej. Kształtujący zasadniczą część tekstu monolog pozostaje tam bowiem wypowiedzią zjawy. Jest nią oczywiście ukazująca się „rozpaczającemu Polakowi" ojczyzna'2, co ważne, przedstawiona przez Brodzińskiego już nie jako wysyłająca potomstwo na bój Matka-Spartanka, ale kobieta przypominająca raczej bolnaterki rodem z literatury frenetycznej - w „zdartej, krwią zbroczonej” szacie „wśród czarnej mgły łona” głosząca swe proroctwo. W kulminacyjnym momencie tegoż przychodzi czas na Napoleona, który występuje tutaj jako „Bohater” obejmujący dłonią „caly glob”; ktoś, kto wskazany zostal przez Boga - tu pobrzmiewają tony urodzinowej ody - by „zniszczyć piekieł złość” skierowaną przeciwko Polakom. Niezwykle popularne w porozbiorowej poezji, zwlaszcza zaś w liryce elegijnej tego okresu, skojarzenie upadającej Rzeczpospolitej z Troją przynosi w pucncic wiersza sugestię każącą widzieć w Napoleonie współczesnego Eneasza -- czlowieka mającego sprawić, że Rzym-Polska „ożyje”. Tym sposobem Wiersz dnia 8 marca 1813 napisany wpisuje się $\mathrm{w}$ tradycję literackiego prowidencjalizmu doby przedromantycznej. Wyrażane w nim przekonanie o wyznaczeniu francuskiemu władcy ściśle określonej roli w Bożym planie nie mogło być zaś, w autorskiej intencji, obojętne dla nastawienia ruszających pod Lipsk żołnierzy księcia Poniatowskiego.

Ani jednak budowana tak właśnic nadzieja na „pogonienie nieprzyjaciól wkoło świata osi", ani tym bardzicj pamiętane z Odły przeświadczenie o potędze Napoleona nie współtworzą nastroju najczęściej clyyba przypominanego wiersza Brodzińskiego z tamtych lat, jakim jest Żotnierz nad rzekq Mosku'q w' r. 1812. Utwór powstały, jeśli ufá́

"Dodajmy, że w pierwszych miesiącach kampanii w wyniku odniesionych ran zmarł także dowódca i przyjaciel Brodzińskiego w jednej osobie, antor Pien uicjskich, Wincenty Reklewski.

:2 „Ojczyzno! Kiedyż przecię i przez jaką siłę / Odwalemy tę straszną na Tobie mogiłę? [...] Łzy się same, krew tylko między nami leje. / Mająż nawet prac tylu zagasnąć nadzieje?" — tak zwraca się on do niej w pierwszych słowach wiersza. 
zapiskom autora, na kilkanaście dni przed rozpoczęciem odwrotu wojsk cesarskich ${ }^{13}$, czytelnie ukazujący to, o czym była mowa na początku niniejszych rozważań — umiejętność łączenia realistycznej dosłowności, wbudowanej w obraz dziejącej się hic et munc historii, z subtelnie zaznaczającym się, moralistycznym komentarzem, zakorzenionym we właściwej sentymentalizmowi etyce umiarkowania.

Samej postaci tego, którego niedawno całkiem pod piórem Koźmiana opatrywano mianem „władcy świata”, w wierszu nie napotkamy, ale też nie ona wyznacza horyzont obserwacji tytułowego żołnierza. Ten tekst zostawia ślad na napoleońskim szlaku pisarstwa Brodzińskiego o tyle, o ile przynosi poruszające wyznanie kogoś, kto, jako jeden $z$ wielı, poszedł za swoim wodzem, aby walczyć na nie swojej ziemi - o ile pozwala usłyszeć wyglaszany z gorzką świadomością niedającej się uniknąć klęski monolog nie bezkrytycznego entuzjasty czy łaknącego otuchy desperata, ale człowieka, którego żadnymi mirażami omamić się już nie zdoła, który w swej prosto artykułowanej mądrości wie, że jego „niwa” zbyt „daleka”, by miał ją kiedykolwiek jeszcze zobaczyć1t.

Tym, co zwraca tam szczególną uwagę, jest uderzająca emocjonalną oszczędnością, a mimo to ujawniająca głębokość przeżycia, tonacja wypowiedzi rozmyślającego „nad zielonym Moskwy brzegiem”, anonimowego uczestnika napoleońskiej kampanii. Korespondując ze sformulowaniami, jakie zawrze autor po latach w rozprawie $O$ elegii, gdzie stwierdzi, że podobna literatura „nie może zajmować gwałtownych uniesień, spokojnym smutkiem tylko być powinna" ${ }^{15}$ — kontrastuje ona z wizyjnymi, czasem" wręcz ekstatycznymi ujęciami, z jakimi mieliśmy do czynienia w tekstach slawiących bosk ość cesarza. Tutaj na irracjonalność nie ma już miejsca, zastępuje ją perspektywa pozbawionej chwały, l ud z k i e j zaledwie śmierci „w zaspach zimy”. W obliczu takiej śmierci Napoleona trudno dostrzec; żolnierska misja — zdaje się mówić Brodziński — kończy się z dala od roztaczanego przez jego wielkość blasku.

Do dwóch spraw warto w tym miejscu się odnieść. Pierwsza to podnoszona czasami zależność tego tekstu od Dumań zotnierza polskiego " starożytnym zamku Mauróu nad Tagiem autorstwa Kantorberego Tymowskiego, przynoszących refleksje tego, który patrzył, jak jego rodacy, bohaterowie napoleońskiej epopei, ,za Pirenejmi położyli kości”. To prawda, że znać tu podobieństwo nie tylko w sferze odczuć mówiącego, tęskniącego za widokiem ,roli ojczystej” i tam pragnącego złożyć swoją „głowę”, ale nawet na poziomie konkretnych scen, czego przykladem wyobrażenie „rolnika hiszpańskie-

Na ten temat zob. sięgające do autografu uwagi Zgorzelskiego, zamieszczone w objaśnieniach do: K. Brodziński, Poe $₫ j e . . .$, t. 1, s. 466.

it Dla właściwej oceny Żotnierza nad rzcki Mosku'l̨... W młodzieńczym dorobku poety znaczące jest, iż wiersz ten zająl poczesne miejsce we wspomnianym tu już parokroć wyborze Pism Brodzińskiego. Powstałych później pod tym samym piórem utworów wskrzeszających wiarę w sens trwania u boku Napoleona próżno byłoby w tej edycji szukać.

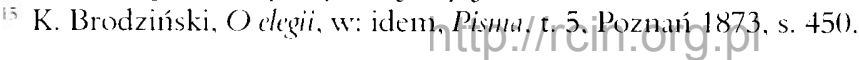


go” — on kiedyś „wyorze [...] szczątki” bezimiennego Polaka „i urągać się będzie z przykrej mu pamiątki”. U Brodzińskiego obraz „odsłoniętych” przez wiosnę zwłok, jakimi „będą rzucać obcych wnuki”, budıje sytuację równie nieheroiczną, równie odległą od ukształtowanych przez mitologiczno-rycerską tradycję ujęć Marsa. Jest jednak istotna różnica. Tymowski dawał mówiącemu w jego tekście żołnierzowi wiarę w to, że podobny los nie musi stać się również jego udziałem, pozwalał mu prosić w pełnej eksklamacji mowie końcowej o „śmierć [...] wśród bratnich szeregów”. Tutaj pozostała jedynie bolesna rezygnacja, wprowadzona w sentymentalny sztafaż „białych brzóz” kryjących mogiły zmarłych i tym bardziej wzmagających żal, że nasuwających skojarzenia z wiosennym otoczeniem opuszczonej na zawsze „chatki”.

Co ważne - i tu przechodzimy do drugiego z sygnalizowanych powyżej problemów - poetycka wypowiedź Brodzińskiego koreluje momentami z tym, co znajdziemy we fragmentach jego Dzicnnika u'ojskou'ego..., a co wkracza w samą ocenę działań Napoleona. W wierszu ocena ta nie jest sformulowana bezpośrednio, kryjąc się za zdradzającymi etyczne dylematy walczącycl stwierdzeniami o „burzeniu obcej [...] krainy". W prowadzonych w innej juz sytuacji historycznej dziennikowych zapiskach poeta-żołnierz pozwala sobie na gloszenie bardziej jednoznacznych sądów, takich chociażby jak ten z 10 sierpnia, kierowany - to kanon czułej frazeologii — do „szczęśliwej prostoty", a będący, co sklaniać musi do pewnych porównań, rezultatem przemyśleń nad atmosferą „uroczystego obchodu [kolejnej rocznicy] cesarskich urodzin”:

Jak łatwo władcom pozyskać sobie serca Twoje, niewchodzące w skrytość zamiarów monarchów, niezapatrujące się w przyszłość. [... Gdyby monarcha mógł się zniżyć do poznania serc tego ludu, nie takjuż szlachetność, sława, powinność urzędu kazałyby myśleć o prawdziwym ich szczęściu. Ale on, często ułudzonych przywiązaniem ku sobie, prowadzi ich tym skuteczniej zamiarom swoim i tym latwiej - na ofiarę ${ }^{1 / .}$.

Do swoich diariuszowych spostrzeżeń dolączal Brodziński od czası do czası pisane w trakcie wojennej marszruty wiersze. Jednym z nich jest tekst o incipicie $W$, dwa u'ynioste dęby, nad u'sia panujące..., stanowiący swego rodzaju dopełnienie wyznań czynionych „nad rzeką Moskwą”, jednocześnie jednak przynoszący ujętą w sentencjonalnej formule próbę podsumowania wokółnapoleonískich doświadczeń pisarza. Nim wybrzmi ono w końcowych wersetach utworu, dostrzegamy, że — podobnie jak to było w tamtym tekście — cała wypowiedź tęskniącego za rodzinnymi stronami zołnierza zasadza się na nad wyraz czytelnym kontraście. Tam uwypuklały go brzozy (był to zresztą pierwotny tytuł wiersza), „wieszające się” w melancholijnym obrazie nad „wody biegiem” i przypominające oddalonemu od ojczyzny Polakowi o czekającej nań 
w ich wspólnej „zagrodzie”, pośród podobnych drzew, Jolencie. Tutaj sentymentalna osnowa tekstu jest nie mniej widoczna, tyle że pojawiające się w katalogu początkowych apostrof, pozwalające zrekonstruować w wyobraźni mówiącego szczęśliwą przestrzeń młodości, „szumiące lasy”, „kwiecistą ląkę” i „wędrowny strumyk” zestawiono już nie z pozbawionymi niemal komentarza wizjami odartej z patosu, degradującej porządek natury śmierci na obczyźnie. Tym razem w kolizję z tak rysowanym wspomnieniem niewinnej przeszłości wchodzą tchnące chęcią rozliczenia, wykrzyczane niemal, operujące nie gorzkim przypuszczeniem, a kategorycznymi stwierdzeniami świadka, oskarżenia autorów wojennej gehenny. Ktoś odpowiada bowiem za „bliźnich mordowanie dla miłości braci”, za „Moskwy pożary”, „łzy dziatek, / pomsty starców skrzywdzonych i przekleństwa matek". Tego kogoś nie wskaże się tu jednak wprost. Pozostanie nienazwany, bo też może niezasługujący na to, by wypowiadane było jego imię — to samo imię, któremu niegdyś w Wężykowej Odzie na pou'rót wojska polskiego do stolicy dawano miejsce „zaraz po Bogu”. Pamięć napoleońskiego etosu będzie musiala się zmierzyć z o tyle dobitniejszą, o ile wykorzystują̧ą technikę konceptu, przypominająca, jako się rzekło, aforyzm, konstatacją:

Najdroższe wieńce - w polu Bellony zbierane,

Przeto może najwięcej, że są podejrzane.

Jakże daleko, podążaąc za cesarską armią, odszedl nasz pisarz od zamykających wiersz-apel Do uojsk polskich zawołań:

Tylko w tych dłoniach oręże

Niech będą, waleczni męże!

Niech byt śmierci lub wolności

Nad brzegami Wisty gości!

W tej poetyckiej drodze dawny Mesjasz i heros powoli stawał się patronem „zlych spraw".

W ciągu dwóch ostatnich lat napoleoniady Brodziński napisal jeszcze kilka przynajmniej wierszy, w których na rozmaite sposoby, chıć na ogół nie wspominając o samym cesarzu, reagował na tę rzeczywistość, za której wspóltwórcę i symbol Napoleon uchodził, ale i którą nierzadko ze względu na jego osobę kontestowano ${ }^{17}$. W tej grupie

- Należaloby tu zaliczyć cykl utworów poświęconych księciu Józefowi, gdzie zresztą powracają dręczące wspomnienia z wyprawy moskiewskiej, kiedy to „ludzie w dzikie zmienili [się] zwierzęta” ( $\mathrm{Na}$ smicré księcia Józcfa Poniatou'skicgo, u'odza u'ojsk polskich); wiersze powstale w związku z obchodami Kongresu Wiedeńskiego (np. Do Kudlicza) czy, pisane już po zrzuceniu munduru, pierwsze z wolnomularskich liryków przyszłego sekretarza loży Wielkiego Wschodu, z ostentacja. być może w ramach odreagowania wojennej traumy, podkreślą̧age myższość żywota „braterskiego" nad ideatem homo militans. 
mieścilby się też utwór, któremu chcielibyśmy poświęcić trochę uwagi w zakończeniu niniejszego artykułu, postrzegając go, w duzej mierze z powodu jego quasi-pamiętnikarskiej formuły, jako liryczne oratio a tumulo Brodzińskiego-żołnicrza, tyleż nostalgiczny, ile mentorski w tonie głos niegdysiejszego napoleończyka.

Wydrukowane dopiero w roku 1819, aczkolwiek napisane zapewne parę lat wcześniej Pole raszyńskie, bo o ten wlaśnie tekst tutaj chodzi, przynosi mianowicie wywołaną „smutnym przypomnieniem” pamiętnej bitwy refleksję nad losem Polski — nad sensem tamtej ofiary. Raszyn, jeden z symboli znamienitości polskiego oręża, literacko tym istotniejszy, że to wlaśnie zdarzenia roku 1809 przyczyniały się w szczególny sposób do utrwalania kultu Bonapartego w rodzimej poezji, staje się tutaj znakiem utraconej szansy, niewynagrodzonego niczym cierpienia, przygnębiającego przemijania nadziei. Raszyńskie pole nie jest polem chwały; jest miejscem, gdzie zza sielankowego z pozoru obrazu pasących się nad potokiem koni wylaniają się natrętnie zarysy zarośniętych chwastem mogil. Duchy pochowanych w nich rycerzy - symboliczna wydaje się tu postać Cypriana Godebskiego, autora antyfrancuskiego przecież w wymowie Wiersza do Legión' Polskich - to wyrzut sumienia tych, którzy wolnościowego testamentu swych wspólbraci nie zrealizowali. Rozlegające się po raszyńskim błoniu, dramatyczne wolanie owych cieni „o [ich] ran owoce” jest bolesną sukcesją po tym, od którego, jak pisał Koźmian w bałwochwalczej niemal Odzic na pożar Mosku'y', ,sam Bóg nie dałby nam więcej”.

Przynosząca skojarzenie z Niemccwiczowską Dumı̨ o Żótkicuskim, prawie w tym samym czasie ponownie opublikowaną w tomie Śpicu'ún historycznych $h^{10}$, sytuacja rozmyślania nad lieroiczną przeszłością nie skutkuje (inaczej więc niż tam) wbudowanym w patriotyczne przesłanie pokrzepieniem. Tutaj aurę przesyconego goryczą wyznania tworzy mająca w tle „upadek dumnego”, dojmująca świadomość niespełnienia, której zdaje się towarzyszyć, wypowiedziane w jednej z ówczesnych bajek Brodzińskiego "', przekonanie, że „najszczęśliwsi - mali: / Nim niskiego burza nagnie, / Wysokiego zwali". Słowa te - wolno sądzić - znacznie lepiej oddają stosunek poety do napoleońskiej przeszłości, także jego wlasnej, niż clyba zbyt pochopnie przypisywany mu przez niektórych, rymowany bon mot:

Nie choce mi się zmieścić we tbie.

Że nasz wódz skończył na Elbie ${ }^{20}$.

is J. U. Niemcewicz, Spie'u'y historycznc, Warszawa 1816.

19 Chodzi tu o wydrukowane po raz pierwszy w roku 1816 Sosicnki.

2" Z podobną atrybucją spotykamy się na przykład w pracy Andrzeja Nieuważnego: $M)^{\prime} \approx$ Nowoleonem, Wroctaw 1999, s. 125. 